\title{
PHENOLOGICAL PHASES OF BUCKWHEAT (Fagopyrum esculentum Mnch.) IN THE PRIMARY AND SECONDARY CROP DEPENDING ON SEEDING RATE
}

\author{
${ }^{1}$ Dariusz Juszczak, ${ }^{2}$ Marian Wesołowski \\ ${ }^{1}$ Institute of Soil and Plant Cultivation, University of Life Science in Lublin, Faculty of Agricultural Sciences in Zamość, \\ Szczebrzeska 102, 22-400 Zamość, Poland \\ e-mail: dariusz.juszczak@up.lublin.pl \\ ${ }^{2}$ Department of Herbology and Plant Cultivation Techniques, University of Life Science in Lublin, \\ Akademicka 13, 20-950 Lublin, Poland
}

Received: 03.02.2011

\begin{abstract}
This paper presents the growth stages of buckwheat grown as a primary or secondary crop as well as using three seeding rates. A field experiment was conducted in the years $2003-2004$ and in 2006 on podzolic soil derived from slightly loamy sand. Phenological observations were made at 5-day intervals, from the time of buckwheat emergence (in the primary crop around 28 May, in the secondary crop 7 June), on selected and properly marked plants. The buckwheat plants were harvested when more than $80 \%$ of buckwheat seeds on them were brown. The duration of particular growth stages of buckwheat are presented in phenological diagrams.

It was found that crop rotation treatment and weather conditions affected significantly the time of occurrence of the phenological phases of buckwheat, but these phases were less dependent on seeding density. A rainfall deficit in 2006 caused a delay in particular growth stages compared to the previous years.
\end{abstract}

Key words: buckwheat, phenological phases, primary crop, secondary crop, seeding rate, weather conditions.

\section{INTRODUCTION}

As a crop plant, common buckwheat has a lot of advantages: it can be grown on poorer soils, has a short growing period, can be sown at different sowing times as a main or secondary crop as well as it is a melliferous plant and a valuable medicinal plant. In spite of its many beneficial and useful features (Fornal and Soral-Śmietana, 1988; Szczukowski and Tworkowski, 1994; Pawłowska and Podolska, 1996; Dietrych-Szóstak and
S u checki, 2003), it is classified as a minor crop. Buckwheat acreage in Poland does not exceed 1\% of the total area of cereal crops (GUS (Polish Central Statistical Office), 2009). The primary reasons for this situation are unfavourable price relations for buckwheat seeds and frequently adverse weather conditions during its particular growth stages. Buckwheat, as a thermophilous plant, requires a quite high temperature for proper emergence, since it dies at temperatures slightly below zero. Heterostyly and the short life span of flowers (they bloom only for one day) has a decisive impact on the number of seeds set. In practice, the percentage of seeds set relative to flowers produced frequently ranges from only 10 to $40 \%$ (R u s z k o w s k i and Now orolnik, 1994; Pecio, 1997). Many authors (K r e f t, 1986; K u s i or s k a et al. 1989) report that the flowering stage can be extended by using sparser sowing or by sowing seeds in wide rows. This results in the development of a larger number of firstand second-level branches as well as a larger number of inflorescences. The extension of this phase increases the probability of pollination by bees, and thus it promotes the number of properly developed seeds on a plant (R u s zk ow ski, 1986; 1988). Buckwheat is a plant that is neutral to day length, but the progress of particular stages is dependent on day length and sowing time (R u s z k ow s k i, 1965).

Phenology, as a science designed to observe periodic life cycle events and their interrelationships ( $\mathrm{S} \mathrm{k} \mathrm{r} \mathrm{z} \mathrm{y} \mathrm{c} \mathrm{z} \mathrm{y} \mathrm{ń} \mathrm{s} \mathrm{k} \mathrm{a} \mathrm{,} \mathrm{2009),} \mathrm{is} \mathrm{frequently} \mathrm{used} \mathrm{in} \mathrm{agri-}$ culture. 
The aim of the present study was to determine the duration of phenological stages of buckwheat in the primary and secondary crop as well as depending on different seeding rates.

\section{MATERIALS AND METHODS}

A field experiment was conducted in the years 2003-2004 and in 2006 in the village of Ruskie Piaski, commune of Nielisz, on podzolic soil derived from slightly loamy sand, classified as a poor rye soil complex. This paper does not include the 2005 results, since a hailstorm destroyed the buckwheat crop in this year. The present study was carried out as a field experiment set up in a split-plot design in three replications with the sowing and harvest plot area of $20 \mathrm{~m}^{2}$. This experimental design included two factors: I. Type of crop: A - primary; B - seconda-

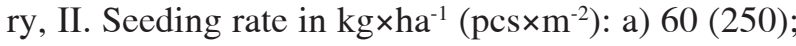
b) 80 (340); c) 100 (430).

In the primary crop, buckwheat was grown following spring cereal mixture (oats + spring barley + spring wheat), whereas in the secondary crop it was grown after a winter cover crop, which was winter rye. Typical tillage was done for growing buckwheat in the primary crop, while for the secondary crop tillage treatments were reduced to spring ploughing (20 cm depth), which was done after the cover crop had been harvested obtaining a yield of $20 \mathrm{t} \mathrm{ha}^{-1}$, and then harrowing was performed.

The soil used in the experiment was characterized by an acidic $\mathrm{pH}$ (5.0), a humus content of $1.17-1.56 \%$ as well as a very high content of phosphorus $(\mathrm{P}=19 \mathrm{mg} / 100 \mathrm{~g}$ of soil $)$, an average potassium content ( $K=12 \mathrm{mg} / 100 \mathrm{~g}$ of soil), and a low magnesium content $-3.0 \mathrm{mg} / 100 \mathrm{~g}$ of soil. The rates of mineral fertilization, in $\mathrm{kg}$ of nutrient per hectare, were as follows: $\mathrm{N}-50, \mathrm{P}-40, \mathrm{~K}-50$. Phosphorus fertilizers (triple superphosphate) and potassium fertilizers $(50 \%$ potassium salt) were applied at the full rate before sowing buckwheat, whereas nitrogen fertilizers (ammonium nitrate) were divided into two portions and the first one $(30 \mathrm{~kg})$ was introduced before sowing, together with phosphorus and potassium fertilizers, while the other one $(20 \mathrm{~kg})$ was applied at bud set.

The buckwheat cultivar 'Hruszowska' was grown and it was sown at a row spacing of $13 \mathrm{~cm}$. For the primary crop, the sowing date was 19-21 May, whereas for the secondary crop it was 30 May. The herbicide Fusilade Forte 150 EC (fluazifop-p-butyl) was used for weed control in the buckwheat crop; it was applied at a rate of $21 \times$ ha $^{-1}$ at the 1-4 leaf stage of monocotyledons weeds and at the 3-4 leaf stage of buckwheat. The buckwheat crop was harvested when more than $80 \%$ of buckwheat seeds were brown.

The occurrence of phenological phases was recorded on the basis of 20 selected and properly marked plants in each plot. Phenological observations were made at 5-day intervals, starting from the date of buckwheat emergence. On the observation days (Table 1), the number of plants that had reached the full growth stage in question was recorded (at least $50 \%$ of the plants had the trait characteristic of a particular phase, e.g. there were $50 \%$ of buds on a plant, etc.).

The results of determinations from the entire growing period of buckwheat were used to calculate the average proportion of a particular phenological phase in a given observation period and then to present this phase in a phenological diagram. Phenological diagrams have the form of large rectangles. A graphic symbol is assigned to each phenophase and it reflects such a phase in the chart depending on its percentage share at a given time. This means that the particular symbol will occupy the whole height of a phonological diagram (rectangle) in the case when only one phenological stage of buckwheat was observed on the respective day of observation. On the other hand, if buckwheat was in different phenological phases at the time of observation, this is reflected in a narrowing of the graphic symbol accordingly, which corresponds to the percentage value of the growth stages of buckwheat recorded at that time. 


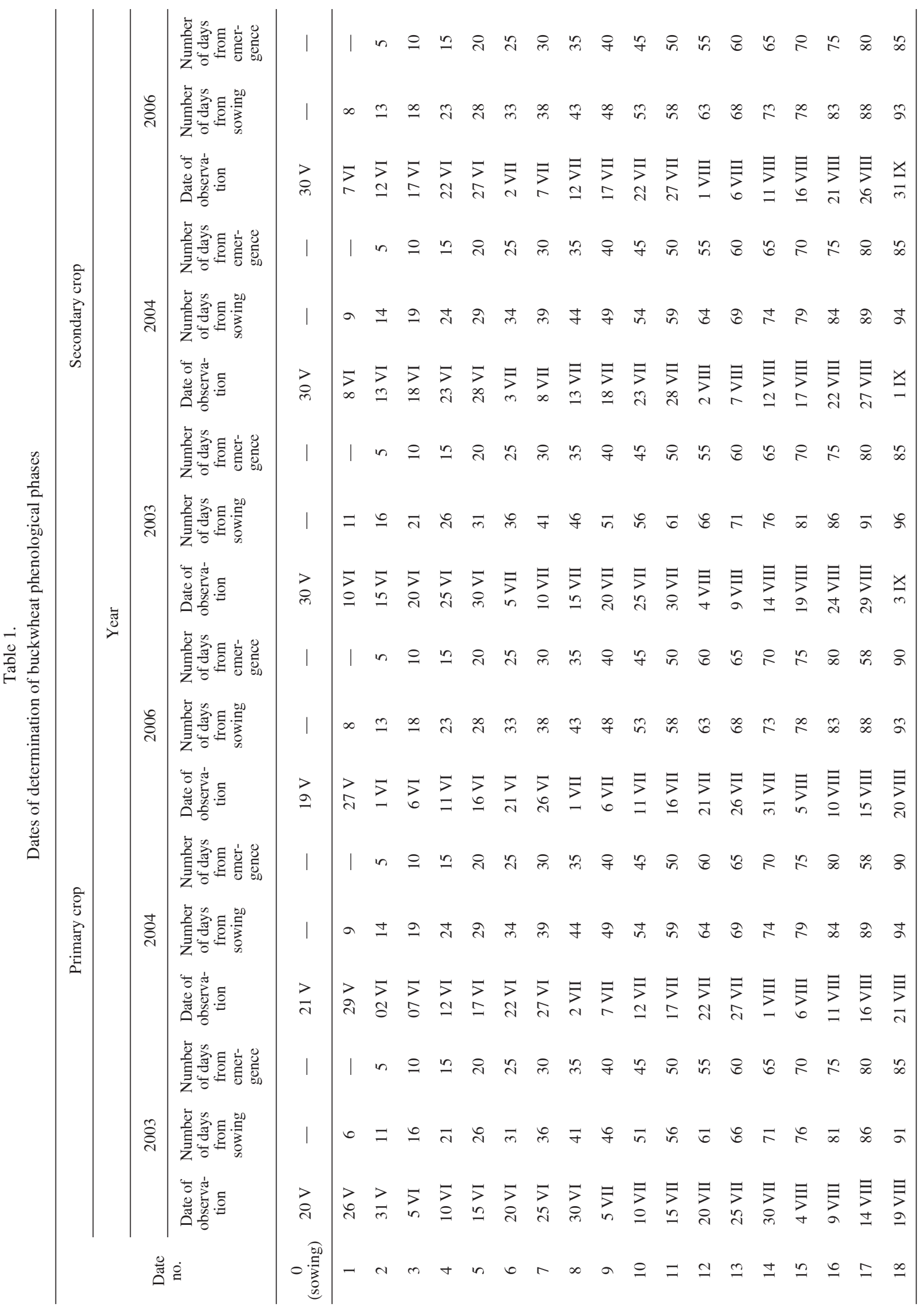




\section{RESULTS}

The weather pattern in particular years of the study was analysed based on the data obtained from the meteorological station of the Faculty of Agricultural Sciences in Zamość (Table 2). Selyaninov's hydrothermal coefficient was used to determine dry and post-drought periods (Table 3 ). This coefficient was calculated according to the following formula (M o l g a , 1958):

$$
K=\stackrel{\mathrm{P}}{0,1 * \sum \mathrm{t}}
$$

where:

$$
\begin{aligned}
& \mathrm{K} \text { - the value of the hydrothermal coefficient, } \\
& \mathrm{P}-\text { monthly total rainfall, } \\
& \mathrm{t} \text { - sum of mean daily air temperatures for a gi- } \\
& \quad \text { ven month. }
\end{aligned}
$$

\begin{tabular}{|c|c|c|c|c|c|c|c|c|c|c|c|c|c|c|c|}
\hline \multirow{3}{*}{ Year } & \multirow{3}{*}{ Decade } & \multicolumn{5}{|c|}{ Total rainfall in $\mathrm{mm}$} & \multicolumn{9}{|c|}{ Mean air temperature in ${ }^{\circ} \mathrm{C}$} \\
\hline & & & & Month & & & \multirow{2}{*}{$\begin{array}{c}\text { Buckwheat } \\
\text { growing } \\
\text { period } \\
\text { V-IX }\end{array}$} & \multirow{2}{*}{ Year } & \multirow{2}{*}{ Decade } & \multicolumn{5}{|c|}{ Month } & \multirow{2}{*}{$\begin{array}{c}\text { Buckwheat } \\
\text { growing } \\
\text { period } \\
\text { V-IX }\end{array}$} \\
\hline & & $\mathrm{V}$ & VI & VII & VIII & IX & & & & V & VI & VII & VIII & IX & \\
\hline & $\mathrm{I}$ & 24.9 & 17 & 106.5 & 0 & 0 & & & I & 17.6 & 19.2 & 18.4 & 19.1 & 14,4 & \\
\hline 2003 & II & 66.7 & 22 & 8 & 5 & 0 & & & II & 15.3 & 18.2 & 19.3 & 20.2 & 12,7 & \\
\hline & III & 19.8 & 6 & 30.2 & 5.8 & 7.9 & & & III & 18.3 & 17.2 & 21.8 & 14.6 & 14,8 & \\
\hline \multicolumn{2}{|c|}{ Total } & 111,4 & 45 & 144.7 & 10.8 & 7.9 & 319.8 & & Mean & 17.1 & 18.2 & 19.8 & 18.0 & 14.0 & 17.42 \\
\hline \multirow[b]{2}{*}{2004} & I & 12.1 & 4.7 & 15.6 & 29.2 & 19.5 & & & I & 15.2 & 18.1 & 19.3 & 19.3 & 16,6 & \\
\hline & II & 4.9 & 10.5 & 13.4 & 12.6 & 1.2 & & & II & 12.7 & 18.1 & 18.7 & 21.1 & 15,8 & \\
\hline \multicolumn{2}{|c|}{ Total } & 50,1 & 34.9 & 145 & 71.9 & 36.3 & 338.2 & $\mathrm{~N}$ & Mean & 13.5 & 18.1 & 19.4 & 19.7 & 14.6 & 17.06 \\
\hline \multirow{3}{*}{2006} & I & 9.6 & 42 & 0 & 73.9 & 0.6 & & & I & 14.3 & 12.6 & 23.5 & 21.4 & 16,3 & \\
\hline & II & 26.9 & 1.1 & 26.1 & 28.6 & 0 & & & II & 16.2 & 19.8 & 21.6 & 18.6 & 17,9 & \\
\hline & III & 17.5 & 0.4 & 2.2 & 42.3 & 0.2 & & & III & 14.0 & 22.8 & 24.7 & 17.1 & 16,1 & \\
\hline \multicolumn{2}{|c|}{ Total } & 54 & 43.5 & 28.3 & 144.8 & 0.8 & 271.4 & & Mean & 14.8 & 18.4 & 23.3 & 19.0 & 16.8 & 18.46 \\
\hline \multicolumn{2}{|c|}{$\begin{array}{c}\text { Long-term } \\
\text { mean } \\
(1971-2005)\end{array}$} & 65,5 & 78.9 & 98.4 & 54.3 & 52.2 & 349.4 & $\begin{array}{r}\text { Lon } \\
\mathrm{m} \\
(197\end{array}$ & $\begin{array}{l}\text { ig-term } \\
\text { nean } \\
1-2005)\end{array}$ & 14.1 & 16.8 & 18.4 & 17.8 & 12.9 & 16.0 \\
\hline
\end{tabular}

Table 2 .

Total rainfall in mm and mean air temperatures in ${ }^{\circ} \mathrm{C}$ according to the Meteorological Station of the Faculty of Agricultural Sciences in Zamość

During the first year of the study (2003), there was a rainfall deficit compared to the long-term mean, coupled with high air temperatures. There was an abundance of rain in May, hence during the time of buckwheat sowing, and in July (Selyaninov's coefficient > 2.01). A distinct rainfall deficiency was observed in the other months, while a spell of drought was recorded from August until the end of the growing period of buckwheat (0.19-0.18).

In 2004 buckwheat grew under different conditions than in 2003. Compared to the long-term mean, the rainfall deficit was then the lowest, since it was only $11 \mathrm{~mm}$. However, such a rainfall pattern during the period May - September was primarily determined by the month of July because as much as $145 \mathrm{~mm}$ of rain was recorded in this month, i.e. $46.6 \mathrm{~mm}$ more than in the period 1971-2005. A period of semi-dro- ught was recorded in the months of June and September. In terms of temperatures, the second year of the study proved to be closest to average conditions, since mean temperature of the growing season of buckwheat exceeded during this period the long-term mean temperature only by $1.5^{\circ} \mathrm{C}$. Temperatures in May and September were closest to average conditions. Temperatures in the summer 2004 were similar to summer temperatures in 2003, that is, they were much higher than in the long-term period.

During the last phase of the study (2006), the lowest amount of rainfall and very high air temperature were recorded. July proved to be particularly dry and hot. High rainfall, exceeding the long-term norm by $64 \mathrm{~mm}$, was recorded as late as August. Therefore, the last season of the study can be generally described as very dry and very warm. 
Table 3 .

Selyaninov's hydrothermal coefficient

\begin{tabular}{ccccccc}
\hline Year & \multicolumn{5}{c}{ Month } & \multirow{2}{*}{ V-IX } \\
\hline & V & VI & VII & VIII & IX & \\
\hline 2003 & 2.11 & 0.82 & 2.35 & 0.19 & 0.19 & 1.13 \\
2004 & 1.19 & 0.64 & 2.41 & 1.18 & 0.83 & 1.25 \\
2006 & 1.17 & 0.79 & 0.39 & 2.45 & 0.02 & 0.96 \\
\hline Mean & 1.49 & 0.75 & 1.72 & 1.28 & 0.34 & \\
\hline
\end{tabular}

The values of Selyaninov's coefficient mean the following:

$0-0.5$ - drought period

$0.51-1.0$ - semi-drought period

1.01-2.0 - relatively wet period

$>2.01$ - high humidity period

In 2003 full emergence of buckwheat in the plots with the seeding rate of $60 \mathrm{~kg} \times \mathrm{ha}^{-1}$ in the primary crop was observed already on the sixth day from the time of sowing (20 May) (Fig. 1). This phase lasted only five days; after this period, buckwheat developed the first pair of true leaves, while after another five days (21 days from sowing) the subsequent pairs of leaves and it started budding. The full bud stage occurred after 26 days from sowing; on day 31 from sowing $20 \%$ of the plants were still at this stage, whereas $73 \%$ were already at the flowering stage. The flowering phenophase extended in time, as long as until 20 July (61 days after sowing) when still $3 \%$ of the buckwheat plants bloomed. From day 41 after sowing (30 June), the flowering stage occurred simultaneously to full seed set. Seed browning started 56 days after sowing. From 4 August, i.e. after 76 days from sowing, almost all buckwheat plants (97\% of their total number) were observed at the stage of brown seeds (80\%) (Fig. 1).

An increased seeding rate up to $80 \mathrm{~kg} \times \mathrm{ha}^{-1}$ in the primary crop only slightly changed the growth cycle of buckwheat compared to the seeding rate of $60 \mathrm{~kg} \times \mathrm{ha}^{-1}$ (Fig. 1). The phase of development of vegetative organs started after six days from sowing (26 May) and lasted until 5 July (46 days from sowing), thus by 5 days longer than in the case of the minimum seeding rate $-60 \mathrm{~kg} \times \mathrm{ha}^{-1}$. The flowering stage started on 20 June and the largest amounts of plants flowered on 25 June ( $94 \%$ of the total number). Seed set lasted equally long as in the plots with the lowest seeding rate (until the end of July). The intensification of this stage in the plots with the seeding rate of $80 \mathrm{~kg} \times \mathrm{ha}^{-1}$ occurred during the period from 10 to 30 July and it was greater than in the treatment with the seeding rate

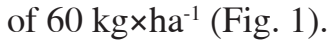

In the case of the maximum seeding rate $(100$ $\mathrm{kg} \cdot \mathrm{ha}^{-1}$ ), the growth of buckwheat was similar to that when the seeding rate of $80 \mathrm{~kg} \times \mathrm{ha}^{-1}$ was applied (Fig.
1). The flowering stage began, similarly as in the case of the seeding rates of 60 and $80 \mathrm{~kg} \times \mathrm{ha}^{-1}$, on 20 June (31 days from sowing), but it lasted only until 5 July (15 days shorter than in the case of sparse sowing). As opposed to the lower seeding rates $\left(60\right.$ and $\left.80 \mathrm{~kg} \times \mathrm{ha}^{-1}\right)$, $100 \%$ of individuals set seeds already on 10 July, i.e. after 51 days from sowing. Seed maturation started on 15 July and this process was parallel to seed set until 4 August. From 4 August, i.e. after 76 days from sowing, all the buckwheat plants were in the phase in which $80 \%$ of seeds were brown (Fig. 1).

In the secondary crop with the seeding rate of $60 \mathrm{~kg} \times \mathrm{ha}^{-1}$, full emergence of buckwheat was recorded after 11 days from the date of sowing, which was done on 30 May (Fig. 1). The early growth stage of buckwheat, i.e. emergence as well as the stage in which the first, second and subsequent pairs of leaves developed, lasted until 15 July. From 30 June, i.e. after 31 days from sowing, the full bud stage was observed and from 5 July the beginning of flowering of buckwheat. Until the time of full flowering, i.e. 15 July, the buckwheat plants were concurrently in 3 growth stages, notably at the vegetative, flower bud and flowering stages. After this period, no buckwheat plants were observed in the vegetative phase and the number of flower buds decreased down to $10 \%$, while the number of flowering individuals increased up to $90 \% .51$ days from sowing (20 July), 20\% of the buckwheat plants were at the seed set stage. On the subsequent dates of observation, the number of seed-setting plants increased, reaching its maximum on 30 July (61 days from sowing) - 77\% of the total number of plants observed. The beginning of seed browning was noticed on 4 August and this process ran parallel to seed set until 24 August, i.e. till day 86 from sowing. Complete browning of $80 \%$ of seeds was noted on 24 August, hence after 86 days from sowing of buckwheat.

The growth of buckwheat in the secondary crop plots with the seeding rate of $80 \mathrm{~kg} \cdot \mathrm{ha}^{-1}$ was similar 
to this process in the case of the seeding rate of 60 kg $\times h^{-1}$ (Fig. 1).

The maximum seeding rate in the secondary crop delayed the growth of buckwheat at the emergence stage compared to the seeding rates of 60 and 80 $\mathrm{kg} \times \mathrm{ha}^{-1}$. The flowering stage also started 5 days later (10 July) and lasted only until day 61 from the date of sowing of buckwheat. Seed set occurred after 56 days from sowing ( $25 \mathrm{July}$ ). In the case of the seeding rate of $100 \mathrm{~kg} \times \mathrm{ha}^{-1}$, full maturity of buckwheat was observed at the same time as in the plots with the seeding rate of 80 $\mathrm{kg} \times \mathrm{ha}^{-1}$. It occurred 86 days from sowing (24 August), that is, this phase took place 5 days earlier relative to the plots with the seeding rate of $60 \mathrm{~kg} \times \mathrm{ha}^{-1}$ (Fig. 1).

In the primary crop, sowing of buckwheat was done on 21 May in 2004. After 8 days, full emergence of the buckwheat plants was observed in all the plots (Fig. 2). On 7 June (18 days from sowing), buckwheat produced the first pair of leaves, and 23 days from sowing (12 June) it developed the second and subsequent pair of leaves. From this moment, the growth of buckwheat depended on the seeding rates applied. In the

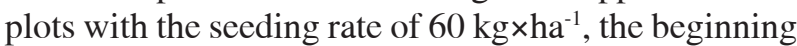
of the flower bud phenophase was observed on day 23 from sowing, while the full bud stage during the period from day 28 to day 38 after emergence. After 38 days from sowing, $3 \%$ of the plants were observed at the vegetative growth stage, $50 \%$ at the flower bud stage, while $47 \%$ at the flowering stage. Full flowering of buckwheat was observed 5 days later, i.e. on 3 July. Concurrently to this phase, seed set began 48 days after sowing, and it lasted with higher or lower intensity as long as until 7 August, i.e. till day 78 from sowing. The beginning of seed browning was observed earlier, since on day 68 of the growth of buckwheat, whereas browning of these organs in $80 \%$ was observed on all the buckwheat plants on 12 August, i.e. after 83 days from sowing.

In the plots with the seeding rate of 80 and 100 $\mathrm{kg} \cdot \mathrm{ha}^{-1}$, the buckwheat plants had more advanced vegetative growth stages from day 28 of the growth compared to the plots with the seeding rate of $60 \mathrm{~kg} \times \mathrm{ha}^{-1}$ (Fig. 2). The flower bud stage was observed on day 28 from sowing in $57 \%$ of the plants in the plots with the seeding rate of $60 \mathrm{~kg} \times \mathrm{ha}^{-1}$, whereas in the plots with the seeding rate of $80 \mathrm{~kg} \times \mathrm{ha}^{-1}$ flower buds were produced by $63 \%$, and in the plots with the seeding rate

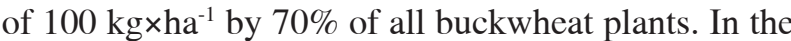

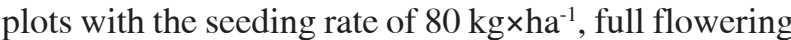
lasted five days shorter (until 17 July). In spite of these differences, complete browning of $80 \%$ of seeds was noted after 83 days from sowing, thus at the same time as in the treatment with the rate of $60 \mathrm{~kg} \times \mathrm{ha}^{-1}$ (Fig.2).

Full emergence of buckwheat grown in the secondary crop in 2004 was observed in all the plots simultaneously, i.e. after 9 days from sowing (Fig. 2). The applied seeding rates did not also differentiate the time of emergence of the first pair and subsequent pairs of leaves in the buckwheat plants. This factor affected noticeably the time of beginning of the flower bud stage; notably, the lower seeding rate was used, the earlier and more abundantly the buckwheat plants set buds. Such a situation lasted from day 24 to day 34 after sowing, and then the proportions in the number of flower buds in the individual treatments equalised. The seeding rates applied clearly modified also the date of start of the flowering stage of buckwheat. In the case of the lowest seeding rate $\left(60 \mathrm{~kg} \times \mathrm{ha}^{-1}\right)$, flowering began on 3 July (34 days after sowing), with the seeding rate of $80 \mathrm{~kg} \times \mathrm{ha}^{-1}$ on 8 July (39 days after sowing), whereas in the plots with the seeding rate of $100 \mathrm{~kg} \times \mathrm{ha}^{-1}$ it occurred as late as 13 July, i.e. 44 days after sowing. Seed set started in the plots simultaneously, i.e. on 18 July (49 days after sowing). Again, buckwheat in the plots with the lowest seeding rate entered earliest the last phenophase, i.e. browning of $80 \%$ of seeds - on 28 July (59 days after sowing). An increase in the seeding rate by $20 \mathrm{~kg} \times \mathrm{ha}^{-1}$ delayed the beginning of seed browning by 5 days, whereas an increase in the seeding rate up to $100 \mathrm{~kg} \times \mathrm{ha}^{-1}$ delayed it by another 5 days compared to the seeding rate of 60 $\mathrm{kg} \times \mathrm{ha}^{-1}$. On the next dates of observation, there was a systematic increase in the number of maturing buckwheat plants, and the final completion of this process was noted in all the plots on 27 August, that is, on day 89 from sowing (Fig. 2).

The experiment involving growing buckwheat in the primary crop in 2006 was set up on 19 May (Fig. 3 ). Emergence (on day 9 from sowing), early growth and the beginning of seed set occurred at the same time in all the plots. The applied seeding rates resulted in differences in the growth of buckwheat only from 22 June, i.e. 34 days from sowing. It was then that the buckwheat plants entered the full bud stage with greater intensity in the plots with the seeding rates of 80 and $100 \mathrm{~kg} \times \mathrm{ha}^{-1}$ in which there was, respectively, $73 \%$ and $64 \%$ of the plants with flower buds compared to $50 \%$ of such plants in the treatment in which the rate $60 \mathrm{~kg} \times \mathrm{ha}^{-1}$ was applied. On the subsequent dates of observation, the growth of buckwheat was more equal in the treatments under comparison. This is manifested in the fact that full flowering was recorded everywhere on 7 July (49 days from sowing), full seed set on 17 July (59 days from sowing), whereas the start of seed browning on 27 July (69 days from sowing). After 79 days from sowing, between $63 \%$ (seeding rate of $100 \mathrm{~kg} \times \mathrm{ha}^{-1}$ ) and $73 \%$ (seeding rate of $60 \mathrm{~kg} \times \mathrm{ha}^{-1}$ ) of seeds became brown, while after 89 days from sowing (16 August) all the plots were characterized by seed browning in $80 \%$ of seeds (Fig. 3). 

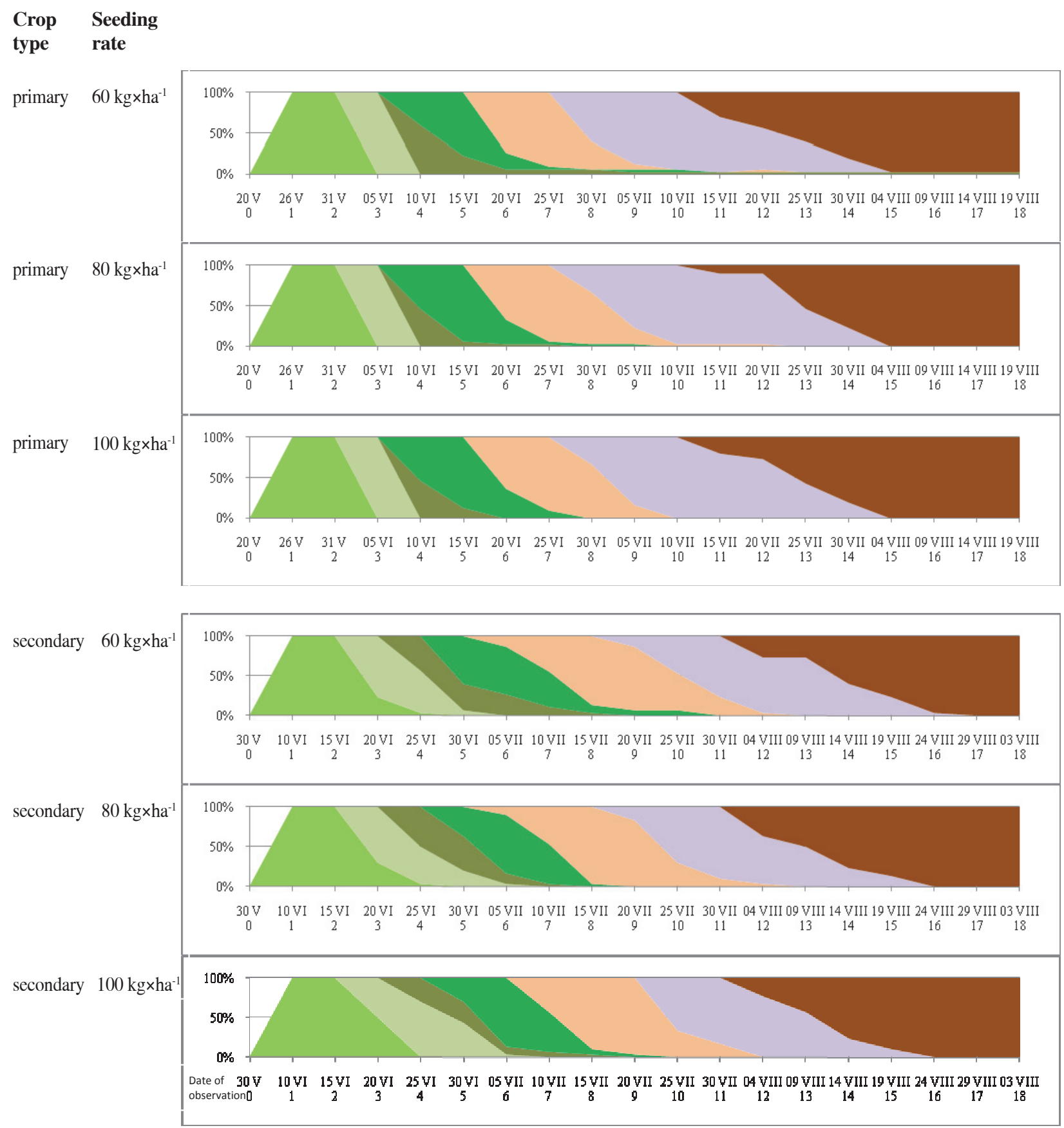

Emergence

First pair of leaves

Subsequent pairs of leaves

Flower buds
Flowering

Seed set

Maturation

Fig. 1. Phenological phases of buckwheat in 2003 


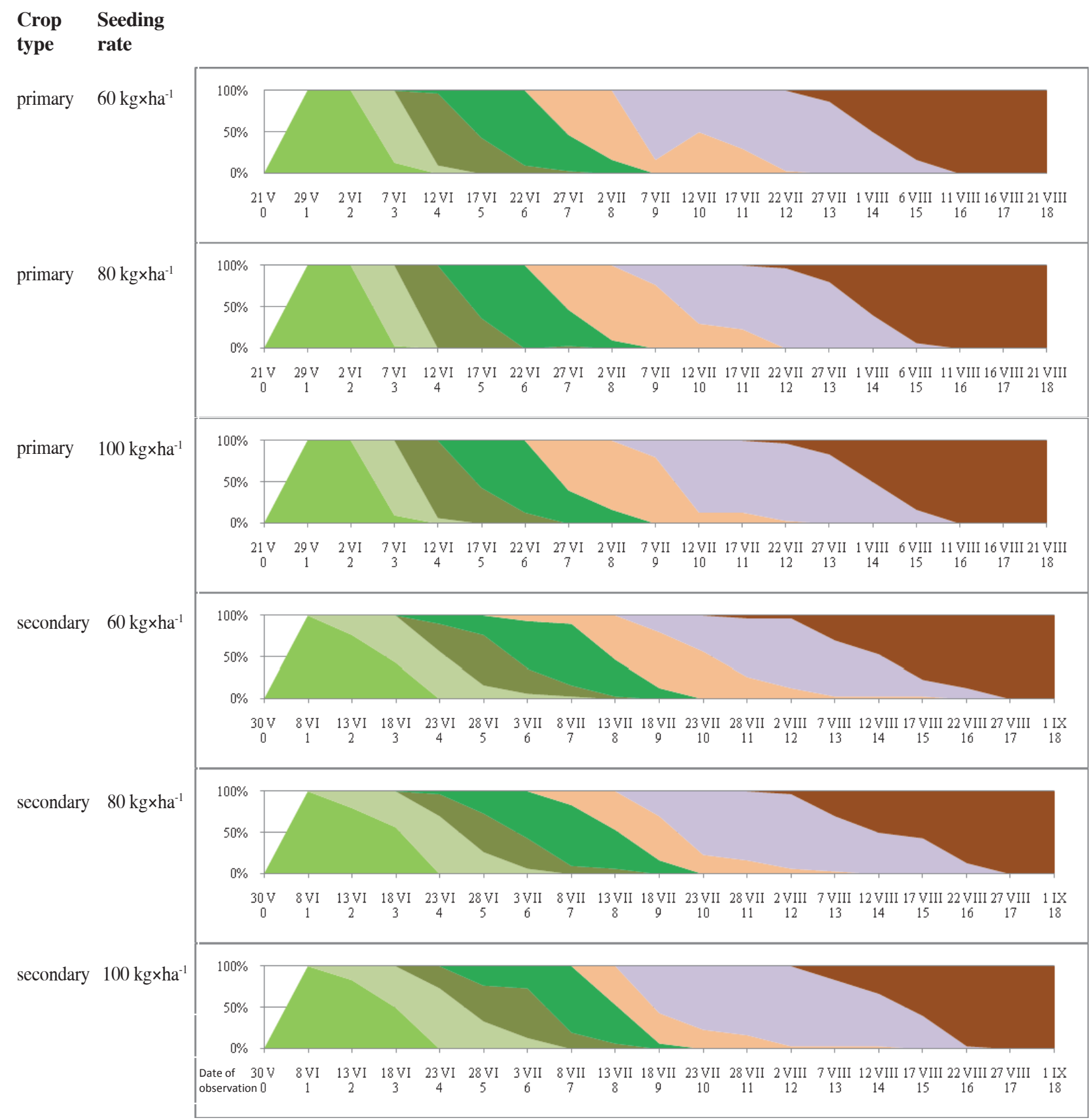

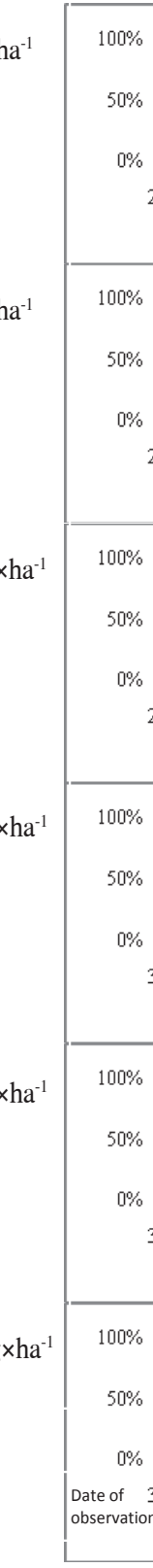

Emergence

First pair of leaves

Subsequent pairs of leaves

Flower buds
Flowering

Seed set

Maturation

Fig. 2. Phenological phases of buckwheat in 2004 


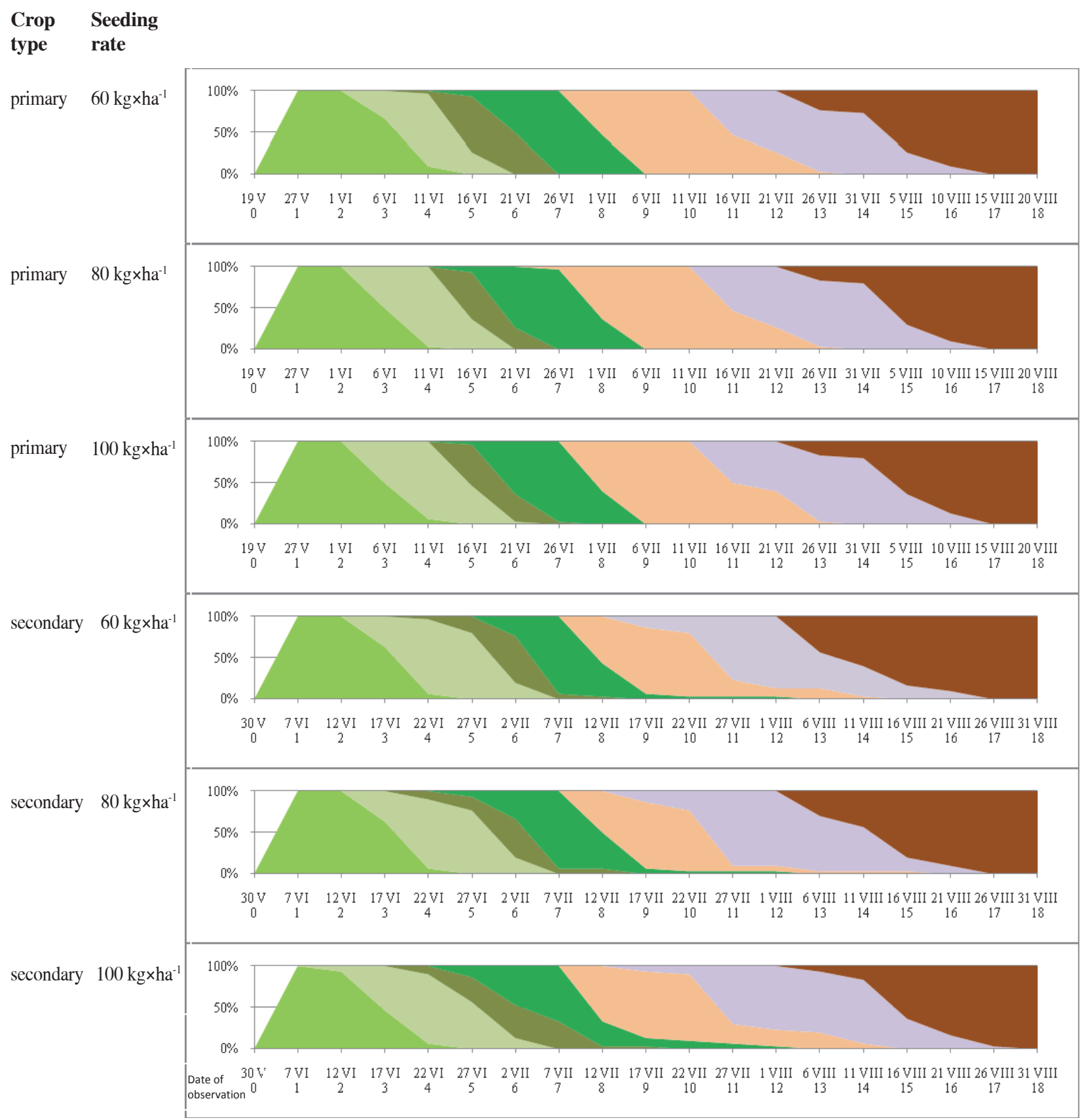

Emergence

First pair of leaves

Subsequent pairs of leaves

Flower buds
Flowering

Seed set

Maturation

Fig. 3. Phenological phases of buckwheat in 2006 
In the secondary crop, buckwheat emerged in all the plots after 8 days from sowing (Fig. 3). In 2006 the compared seeding rates differentiated only the time of emergence and the intensity of the vegetative growth stages of buckwheat. Flower buds on the buckwheat plants were set earliest in the case of the seeding rates of 80 and $100 \mathrm{~kg} \times \mathrm{ha}^{-1}-27$ June (after 28 days from sowing). When the seeding rate of $60 \mathrm{~kg} \times \mathrm{ha}^{-1}$ was applied, the onset of the above-mentioned phenophase was observed 5 days later (2 July). Full flowering of the buckwheat plants was recorded in all the plots on 12 July and this phase lasted until 22 July, i.e. till day 53 from sowing. Relatively more buckwheat plants reached this phenophase in the treatments with the increased seeding rates than in the plots with the seeding rate of $60 \mathrm{~kg} \times \mathrm{ha}^{-1}$. Seed set started earlier in the plots with the seeding rates of 60 and $80 \mathrm{~kg} \times \mathrm{ha}^{-1}-17$ July (48 days after sowing) - than in the plots with the seeding rate of $100 \mathrm{~kg} \cdot \mathrm{ha}^{-1}-22$ July. Full seed set lasted from 27 July to 11 August, while in the plots with the seeding rate of $60 \mathrm{~kg} \times \mathrm{ha}^{-1}$ only until 1 August. The end of this process was noticed on 21 August, when from 83\% (seeding

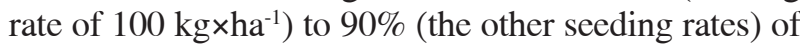
the plants had brown seeds in $80 \%$. Complete maturation of seeds in all the secondary crop plots occurred on 31 August, i.e. after 93 days from sowing (Fig. 3).

\section{DISCUSSION}

In the present study, the growth cycle of buckwheat during study years is illustrated in phenological diagrams (Figs 1-3). Such a method of presentation of buckwheat phenology has no equivalent in the literature of the subject. In the available literature, the growth and development of buckwheat has been thus far described by using only tabulated data that most frequently specify the number of days from the date of sowing until the date of occurrence of more important growth stages, the duration of inter-stage periods (S z k l a r z, 1965; M a z u r e k, 1966), or the duration of the growing period. The present authors, wishing to refer to the buckwheat growth cycle so presented, have also prepared relevant tabulated data under this study (Tables 4 and 5).

A comparison of the data contained in the phenological diagrams and of the tabulated data shows that the type of crop changed buckwheat phenology most of all, while study years and seeding rates changed it to a smaller extent. In the secondary crop, which is associated, among others, with a later sowing date, the period of buckwheat emergence generally lasted longer than in the primary crop. The emergence stage was longer particularly in 2003, when a rainfall deficit was recorded at the end of May and at the beginning of June, coupled with very high air temperature. As a result of abundance of rain and much lower temperatures, which were less dry, in the 1st decade of June 2006 full emergence of buckwheat was observed in the secondary crop already after eight days, hence faster by 1 day than in the primary crop in the case of which sowing had been done during a post-drought period. The rate of emergence and the development of the first pair and then of subsequent pairs of leaves affected the dates of occurrence of the generative growth stages. In the primary crop, these stages occurred faster in the years 2003 and 2004 than in the secondary crop, whereas in 2006 the situation was reverse, as a rule. The growth cycle of buckwheat in the types of crop under comparison became the same in 2006 only at the end of the vegetation process of this plant. As a result of that, the duration of its growing period, calculated from the time of sowing to browning of $80 \%$ of seeds, lasted equally long in both crop types. The plots with the seeding rate of $100{\mathrm{~kg} h \mathrm{~h}^{-1}}$ were an exception here, as the growing period lasted 89 days in the primary crop, whereas in the secondary crop 93 days. Taking into account only the length of the growing period of buckwheat, in the primary crop it lasted from 76 days in 2003 up to 89 days in 2006, while in the secondary crop from 86-91 days in 2003 up to 88-93 days in 2006 (Tables 4 and 5).

The seeding rates differentiated buckwheat phenology in an ambiguous way as well as to a small extent and only in some growing seasons. An increase

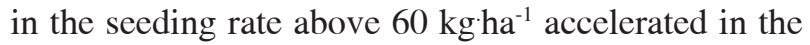
primary crop the stage of flower bud set in 2003 and full flowering in 2004 (Table 4). In the secondary crop, higher seeding rates delayed the phenological phases of full bud stage and full flowering in 2003, whereas in 2004 they accelerated full seed set (Table 5).

The studies of other authors have not generally carried out such frequent observations of buckwheat growth as in the present study. Furthermore, at most the effect of sowing date on the time of occurrence of the main phenological phases has been analysed in these studies, but the effect of seeding density on the growth cycle of buckwheat has not been addressed at all. Research on other cultivars than cv. 'Hruszowska', grown in the study under discussion, has been frequently conducted. In the opinion of $\mathrm{Szklarz}$ et al. (1988), the growing period of the cultivar 'Hruszowska' in the eastern part of the Lublin region (in the area of the city of Parczew) lasted from 103 to 130 days, whereas according to Ko men d a et al. (1973) only 76-84 days at the Plant Breeding Station in Jeleniec (Lublin region).

In the opinion of $\mathrm{Mazure \textrm {k }}$ and $\mathrm{Podolska}$ (2001) as well as Liszewski (1999), late sowing dates contribute to a shortening of the growing period of buckwheat as well as they cause a shortening of the period from sowing to emergence (L i s z e w s k i, 1997) 
and from sowing to flowering ( $\mathrm{M} \mathrm{a} \mathrm{z} \mathrm{u} \mathrm{re} \mathrm{k}$ and $\mathrm{Po}$ dolska, 2001). It should be added here that $\mathrm{Ma}$ $\mathrm{z}$ u re k and Podolska carried out their observations on the cultivars 'Panda', 'Kora', and 'Luba', whereas Li s ze w ski on the cultivar 'Emka'. Fatyga (1988) claims that earlier sowing accelerates flowering but shortens the period of vegetative growth in favour of generative growth; in the opinion of $\mathrm{M} \mathrm{az} \mathrm{u} \mathrm{re} \mathrm{k}$ and Podolska (2001), it is associated with the photoperiodic response of buckwheat. According to K o m e $\mathrm{n}$ d a et al. (1973), the cultivar 'Hruszowska' emerged after 5-10 days from sowing, whereas it flowered after 28-31 days from sowing. In the opinion of $\mathrm{S} \mathrm{z} \mathrm{k} 1$ a r z et al. (1988), the same cultivar produced the first pair of leaves 7-9 days after emergence, while it fully matured after 76-81 days from sowing.
In the present study, the response of buckwheat to the type of crop, thus indirectly to the sowing date, was sometimes different than that reported in the literature of the subject. It could have resulted from the fact that the distance between the sowing dates was too small, since it was only 10 days. In the study of $\mathrm{Li}$ s z e w s k i $(1997,1997 a)$, the distance between the sowing dates was more than one month (the 3 rd decade of April and the 3rd decade of May), while in the study of Mazurek and Podolska (2001) it was as much as more than two months (6 May - 14 July). Therefore, in the situation existing during the studies conducted by these authors, the response of buckwheat to day length could have manifested itself, though in the opinion of Ruszkowska and Ruszkowski (1981) buckwheat is a photoperiodically neutral plant.

Table 4.

Buckwheat growing pattern in the primary crop

\begin{tabular}{|c|c|c|c|c|c|c|c|c|c|}
\hline \multirow{7}{*}{ Specification } & \multicolumn{9}{|c|}{ Year } \\
\hline & \multicolumn{3}{|c|}{2003} & \multicolumn{3}{|c|}{2004} & \multicolumn{3}{|c|}{2006} \\
\hline & \multicolumn{9}{|c|}{ Seeding rate in $\mathrm{kg} \times \mathrm{ha}^{-1}$} \\
\hline & 60 & 80 & 100 & 60 & 80 & 100 & 60 & 80 & 100 \\
\hline & \multicolumn{9}{|c|}{ Sowing date } \\
\hline & $20 \mathrm{~V}$ & $20 \mathrm{~V}$ & $20 \mathrm{~V}$ & $21 \mathrm{~V}$ & $21 \mathrm{~V}$ & $21 \mathrm{~V}$ & $19 \mathrm{~V}$ & $19 \mathrm{~V}$ & $19 \mathrm{~V}$ \\
\hline & \multicolumn{9}{|c|}{ Number of days from sowing } \\
\hline Full emergence & 6 & 6 & 6 & 8 & 8 & 8 & 9 & 9 & 9 \\
\hline First pair of leaves & 16 & 16 & 16 & 18 & 18 & 18 & 24 & 19 & 19 \\
\hline Subsequent pairs of leaves & 21 & 21 & 21 & 23 & 23 & 23 & 29 & 29 & 29 \\
\hline Full bud stage & 26 & 26 & 26 & 28 & 28 & 28 & 34 & 34 & 34 \\
\hline Full flowering & 31 & 31 & 31 & 38 & 38 & 38 & 44 & 44 & 44 \\
\hline Full seed set & 41 & 46 & 46 & 53 & 53 & 53 & 59 & 59 & 59 \\
\hline Browning of $80 \%$ of seeds & 76 & 76 & 76 & 83 & 83 & 83 & 89 & 89 & 89 \\
\hline
\end{tabular}

Table 5 .

Buckwheat growing pattern in the secondary crop

\begin{tabular}{|c|c|c|c|c|c|c|c|c|c|}
\hline \multirow{7}{*}{ Specification } & \multicolumn{9}{|c|}{ Year } \\
\hline & \multicolumn{3}{|c|}{2003} & \multicolumn{3}{|c|}{2004} & \multicolumn{3}{|c|}{2006} \\
\hline & \multicolumn{9}{|c|}{ Seeding rate in $\mathrm{kg} \cdot \mathrm{ha}^{-1}$} \\
\hline & 60 & 80 & 100 & 60 & 80 & 100 & 60 & 80 & 100 \\
\hline & \multicolumn{9}{|c|}{ Sowing date } \\
\hline & $30 \mathrm{~V}$ & $30 \mathrm{~V}$ & $30 \mathrm{~V}$ & $30 \mathrm{~V}$ & $30 \mathrm{~V}$ & $30 \mathrm{~V}$ & $30 \mathrm{~V}$ & $30 \mathrm{~V}$ & $30 \mathrm{~V}$ \\
\hline & \multicolumn{9}{|c|}{ Number of days from sowing } \\
\hline Full emergence & 11 & 11 & 11 & 9 & 9 & 9 & 8 & 8 & 8 \\
\hline First pair of leaves & 21 & 21 & 21 & 19 & 24 & 19 & 23 & 23 & 18 \\
\hline Subsequent pairs of leaves & 26 & 26 & 26 & 29 & 29 & 33 & 33 & 33 & 33 \\
\hline Full bud stage & 31 & 36 & 31 & 33 & 33 & 38 & 38 & 38 & 38 \\
\hline Full flowering & 46 & 46 & 46 & 48 & 48 & 43 & 43 & 43 & 43 \\
\hline Full seed set & 61 & 56 & 56 & 58 & 53 & 48 & 58 & 58 & 58 \\
\hline Browning of $80 \%$ of seeds & 91 & 86 & 86 & 88 & 88 & 88 & 88 & 88 & 93 \\
\hline
\end{tabular}




\section{CONCLUSIONS}

The occurrence and intensity of the investigated phenological phases of buckwheat were dependent to the greatest extent on the type of crop, but to a lesser degree on weather conditions during the growth of buckwheat. The seeding rate was of least importance in the present experiment.

A lower amount of rainfall in 2006 caused a delay in the growth stages of buckwheat grown in the primary crop by six days compared to the previous years.

\section{REFERENCES}

Dietrych-Szóstak D., Suchecki Sz., 2003. Wybrane cechy jakościowe nasion polskich odmian gryki. / Some qualitative traits of seeds of Polish buckwheat cultivars. Pam. Puławski, 133: 35-41. (in Polish)

Fatyga J., 1988. Doskonalenie technologii uprawy gryki. / Improving buckwheat cultivation technology. V kraj. Symp. nt. „Hodowla, agrotechnika i jakość gryki. Wyd. IUNG Pulawy: 38-50. (in Polish)

Fornal Ł., Soral-Śmietana M., 1988. Gryka krajowym surowcem do otrzymywania żywności profilaktycznej. / Buckwheat as a domestic raw material for obtaining preventive food. V Krajowe Symp. nt. „Hodowla, agrotechnika i jakość ziarna gryki”. Lublin 1415 July 1988. Wyd. IUNG Puławy: 51-65. (in Polish)

Komenda B., Komenda K., Szklarz J., 1973. Produktywność gryki tetra - i diploidalnej. / Productivity of tetra - and diploid buckwheat. Hod. Rośl. Aklim. Nasien. 17(6): 441-445. (in Polish)

K reft J ., 1986. Physiology of buckwheat yield. Proc. $33^{\text {rd }}$ Intl. Symp. On Buckwheat, Puławy, Poland, Part I: 37-50.

Kusiorska K., Kozaczenko H., Szczukowski S., Tworkow ski J., 1989. Technologia uprawy gryki na nasiona w regionie olsztyńskim. / Technology of cultivation of buckwheat grown for seeds in the Olsztyn region. ART. Olsztyn. (in Polish)

Liszewski M., 1997. Zmienność rozwoju i wzrostu gryki pod wpływem terminu siewu i ilości wysiewu w zróżnicowanych warunkach glebowych. / Variations in the development and growth of buckwheat as influenced by sowing date and seeding rate under different soil conditions. Mat. X Symp. Nauk. nt. „Hodowla, uprawa i wykorzystanie gryki”. Wyd. IUNG Puławy, R (341): 23-45. (in Polish)

Lis zewski M., 1997a. Reakcja gryki na terminy i gęstość siewu w zależności od warunków glebowych i atmosferycznych. / Response of buckwheat to sowing dates and seeding density depending on soil and atmospheric conditions. Zesz. Nauk. AR we Wrocławiu, Rolnictwo, 70, 316: 199-207. (in Polish)

Li s ze w ski M., 1999. Reakcja gryki na wczesny termin siewu w zależności od zróżnicowanych warunków atmosferycznych. / Response of buckwheat to early sowing date depending on different atmospheric conditions.
Fol. Univ. Agric. Stetin. 202, Agricultura, 79: 139-142. (in Polish)

Mazu rek J., 1966. Wpływ nawożenia i wilgotności podłoża na wzrost, przebieg wegetacji oraz owocowania gryki. / The effect of fertilization and soil moisture content on the growth, vegetation process and fruiting of buckwheat. Pam. Puławski, 21: 3-39. (in Polish)

Mazurek., Podolska G., 2001. Dynamika wschodów oraz plonowanie nowych odmian gryki w zależności od terminu siewu. / The rate of emergence and yield of new buckwheat cultivars depending on sowing date. Zesz. Nauk. AR w Krakowie, 392: 71 - 81. (in Polish)

Molga M., 1958. Meteorologia rolnicza. Warszawa: 550556. (in Polish)

Pawłowska J., Podolska G., 1996. Technologia uprawy gryki. / Buckwheat cultivation technology. Materiały szkoleniowe 47/96. Wyd. IUNG Puławy: 11-23. (in Polish)

Pe ci o A., 1997. Morfologiczny model rośliny i łanu gryki oraz jej plonowanie w zależności od rozmieszczenia roślin na jednostce powierzchni. / A morphological model of the buckwheat plant and crop as well as its yield depending on plant distribution per unit area. Mat. X Krajowego Symp. nt. „Hodowla, uprawa i wykorzystanie gryki”. Wyd. IUNG Puławy: 63-79. (in Polish)

Rocznik Statystyczny Rzeczpospolitej Polskiej. 2009. GUS, Warszawa. (in Polish)

Ruszkowska B., Ruszkowski M., 1981. „Gryka”, Państwowe Wydawnictwo Rolnicze i Leśne, Warszawa. (in Polish)

Ruszkowski M., Noworolnik K., 1994. Gryka. Zalecenia agrotechniczne. Technologie uprawy roślin. / Buckwheat. Agrotechnical recommendations. Plant growing technologies. Wyd. IUNG Puławy, ser. $\mathrm{P}(56 / 10)$. (in Polish)

Rus zkowski M., 1965. Studia nad gryką. Zależność między wzrostem i rozwojem a plonowaniem. / A study on buckwheat. A correlation between growth and development and yield. Cz. I. Pam. Puławski 19. (in Polish)

Ruszkowski M., 1986. Productivity of buckwheat. Proceedings of the 3-rd International on Buckwheat Research. Puławy Poland.

Ruszkowski M., 1988. Zmiany w strukturze plonu i architekturze łanu gryki pod wpływem czynników agrotechnicznych. / Changes in the yield structure and in the buckwheat crop architecture under the effect of agrotechnical factors. [In:] Praca zbiorowa. Ważniejsze elementy agrotechniki odmian gryki, M. Ruszkowski, K. Noworolnik (eds), Wyd. IUNG Puławy, ser. R(241): 41-66. (in Polish)

S kr z y c z y ń ska J ., 2009. Wybrane zagadnienia z ekologii. Akademia Podlaska Siedlce. (in Polish)

Szczukowski S., Tworkowski J., 1994. Gryka, roślina alternatywna o wielorakich możliwościach wykorzystania. / Buckwheat, an alternative plant with multiple use possibilities. Fragm. Agronom. 3: 55-59. (in Polish) 
Szklarz J., Wójcik S., Dawidziuk H., 1988. Wpływ zróżnicowanego nawożenia mineralnego na plonowanie gryki. / The effect of different mineral fertilization on buckwheat yield. Mat. V Krajowego Symp. nt. „Hodowla, agrotechnika i jakość ziarna gryki”. Lublin, 14-15 July 1988. Wyd. IUNG Puławy: 142-150. (in Polish)

Szklarz J., 1965. Wpływ okresowej suszy glebowej na wzrost i rozwój gryki (Fagopyrum esculentum Moench). / The effect of short-term soil drought on the growth and development of buckwheat. Hod. Rośl. Aklim. i Nasien. 9(5): 549-575. (in Polish)

S z k la r z J ., 1988. Wpływ węglanu wapnia na wzrost, rozwój i plonowanie gryki. / The effect of calcium carbonate on the growth, development and yield of buckwheat. V Kraj. Symp. nt. „Hodowla, agrotechnika i jakość gryki, Lublin 14-15 July 1988. Wyd. IUNG Puławy: 151-161. (in Polish)
Fazy fenologiczne

gryki zwyczajnej (Fagopyrum esculentum Mnch.) w plonie głównym i wtórym w zależności od gęstości siewu

\section{Streszczenie}

W pracy przedstawiono rozwój fazowy gryki uprawianej w plonie głównym i wtórym oraz w trzech gęstościach siewu. Doświadczenie polowe przeprowadzono w latach 2003-2004, 2006 na glebie bielicowej wytworzonej z piasków słabo gliniastych. Obserwacje fenologiczne prowadzono w odstępach 5-dniowych od momentu wschodów (w plonie głównym około 28 maja, w plonie wtórym 07 VI June) na wybranych i odpowiednio oznaczonych roślinach. Zbioru roślin dokonano gdy $80 \%$ orzeszków na roślinie było zbrunatniałych. Czas trwania poszczególnych faz gryki przedstawiono na fenogramie.

Zauważono, że stanowisko $w$ zmianowaniu oraz warunki pogodowe w znacznym stopniu wpływały na termin pojawiania się faz fenologicznych gryki. W mniejszym stopniu fazy te były uzależnione od gęstości siewu. Deficyt opadów w 2006 powodował opóźnienie poszczególnych faz rozwojowych w porównaniu z latami poprzednimi. 